\title{
BUNGA BANK: ANTARA PARADIGMA TEKSTUAL DAN KONTEKSTUAL
}

\author{
Muhammad Syarif Hasyim \\ STAIN Datokarama Palu, Jl. Diponegoro 23 Palu \\ e-mail: m.syarif.hasyim@gmail.com
}

\section{Abstract}

Bank interest is an interesting topic to discuss from classical era to modern era. In classical era, interest has been decided as ribâ., the law status of which is harâm (forbidden) because of an addition (ziyâdah). Based on this, bank interest is also categorized as ribâ. Nevertheless, some say that the forbiddance of riba is because of an exploitation to the clients, based on which bank interest is not ribâ. It is based on these two opinions that a controversy on bank interest emerges. The controversy emerges since the first group interprets the verses on ribâ textually while the second group interprets the verses contextually.

$$
\begin{aligned}
& \text { فوائد البنوك من المثارة جدلا، وخاصة فى الاونة الأخيرة، هل هذه الفوائد } \\
& \text { حرام ام لا. ومن العلماء من قال انها حرام لانها من الربا وبعضهم من قال }
\end{aligned}
$$

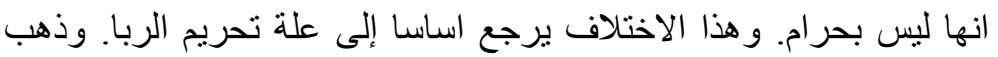

$$
\begin{aligned}
& \text { بعضهم إلى ان علة تحريمه هي مطلق الزيادة، و على اساس هذا الرأي فتكون } \\
& \text { فوا ئد البنوك من الربا وهي محرم. وبعضهم من قال ان علة تحريمه هي } \\
& \text { الظلم والاحتكار، ففوائد البنوك ليس بمحرم، لان المعاملات البنوكية } \\
& \text { أساسهاالرضا بين الطرفين. وكلا الطرفين يفهمان ايات الربا فهما مختلفا. } \\
& \text { فالفريق الاول يميل إلى فهم النصوص فهما لفظيا أو نصيا، اما الفريث الثانى } \\
& \text { فيميل إلى فهم معنوى أو سياقى. }
\end{aligned}
$$

Kata Kunci: bunga bank, paradigma tekstual, paradigma kontekstual 


\section{PENDAHULUAN}

Bank adalah suatu badan yang bergerak di bidang jasa, sudah sewajarnya apabila setiap bank menginginkan adanya imbalan (keuntungan) atas jasa yang mereka sediakan. Melalui imbalan tersebut sebuah bank akan mampu mengembangkan dirinya dan menjamin eksistensinya di tengah-tengah para nasabahnya. Hanya saja, imbalan tersebut (yang kemudian disebut dengan istilah "bunga") dalam prakteknya terkesan mengeksploitasi nasabah, khususnya dalam sistem kredit. Di mana setiap pinjaman kredit pasti disertai dengan persentase bunga, baik bunga modal maupun bunga jatuh tempo.

Dengan demikian, kesan yang timbul dengan praktek tersebut, bahwa bank sudah menjadi salah satu wadah yang menjalankan praktek riba, karena kata "riba" dalam bahasa Arab menurut alAsymawy, senantiasa diidentikkan dengan sesuatu yang bertambah, baik itu berasal dari harta yang dihalalkan atau yang diharamkan (AlAshmâwî, 1996:32).

Dalam nas $\square$ eksistensi hukumnya sangat jelas sebagai sesuatu yang diharamkan. Sebagaimana disebutkan dalam Q.S Al-Baqarah [2]: 275 :

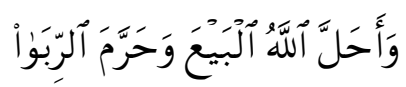

Terjemahnya:

\section{Dan Allah menghalalkan jual-beli serts mengharamkan riba}

Para fuqahâ' dan cendekiawan Islam sejak zaman Rasulullah hingga sekarang telah sepakat bahwa riba adalah bentuk mu'amalah yang diharamkan hingga akhir zaman, apalagi hal itu juga diakui oleh semua syari'at agama samawi lainnya.

Namun demikian, ada yang berpendapat bahwa transaksi yang terjadi di bank merupakan bentuk muamalah modern (baru) dalam dunia Islam, sehingga status hukumnya perlu mendapat penjelasan. Di kalangan ulama Islam terjadi sudut pandang yang berbeda sejak tahun 1930-an hingga sekarang. Perbedaan ini tidak terlepas dari paradigma berpikir mereka, yaitu cara berpikir tekstual dan kontekstual. Dengan demikian kasus ini dapat dikategorikan sebagai masalah ijtihâdiyyahkhilâfiyyah (Minhajuddin, 1997:149). 


\section{DASAR PERBEDAAN PENDAPAT}

Setidaknya ada dua hal yang menjadi titik perdebatan dalam masalah bunga bank, yaitu (1) apakah bunga bank sekarang sama bentuknya dengan riba yang diharamkan pada masa pra-Islam?; dan (2) apakah bunga bank (khususnya bunga pinjaman) menguntungkan kedua belah pihak yang bertransaksi (bank dan nasabah) atau justeru mengeksploitasi/merugikan salah satunya?

Secara umum, polemik tersebut dilatarbelakangi oleh tiga aspek mendasar, yaitu (1) karena prinsip dasar muamalat dalam Islam bersumber dari nass yang sifatnya umum dan tidak rinci, maka peluang untuk berijtihad di dalamnya amat terbuka luas; (2) perbedaan ulama dalam menentukan hal yang menjadi illat pengharaman riba, antara ziyâdah (tambahan), ad'afan mudâ'afan (berlipat ganda) atau $z \square$ ulm (aniaya) (Muslihun, 2004:119); (3) perbedaan Ulama sejak masa sahabat hingga sekarang mengenai bentuk-bentuk riil riba yang diharamkan dalam nass (Ibn Kathîr, 1994: 309-310).

Penelitian yang dilakukan oleh Abdullah Saeed (2003:11) menunjukkan bahwa pada abad ke-19 dan ke-20, wacana mengenai polemik bunga bank dalam dunia Islam terbagi kepada dua kubu, yaitu Modernis dan neo-Revivalis. Kubu modernis yang muncul kira-kira pada paruh kedua abad ke-19 M., menurut Mohammad Iqbal, mempunyai ciri-ciri di antaranya (1) selektif dalam menggunakan sunah; (2) mengembangkan pola berpikir sistematis dengan menghilangkan anggapan yang meyakini bahwa pintu ijtihad telah tertutup; (3) membuat perbedaan antara syari'ah dan fikih; (4) Menghindari paham yang menonjolkan sektarian; dan (5) mengubah karakteristik metode berpikir. Para modernis dalam memahami sebuah fenomena tertentu selalu memperhatikan situasi dan kondisi yang melatarbelakangi munculnya fenomena tersebut, baik dari segi moral, agama, maupun setting sosial historis.

Dalam menganalisis masalah bunga bank, kelompok modernis menekankan akan pentingnya melakukan penyegaran pemikiran Islam dengan cara membangkitkan kembali gelombang ijtihad sebagai sarana untuk memperoleh ide-ide yang relevan dari Alquran dan Sunnah, dan berusaha memformulasikan kebutuhan hukum berdasarkan pada dua sumber tersebut.

Kaum modernis cenderung lebih kontekstual dalam pembahasannya, artinya dalam memahami suatu fenomena, mereka selalu memperhatikan situasi dan kondisi yang melatarbelakangi 
munculnya fenomena tersebut (Muslihun, 121). Oleh karena itu, mereka membedakan bunga bank dengan riba, sebab menurut mereka yang menjadi pertimbangan rasional pelarangan riba pada masa praIslam adalah terletak pada aspek moral, yaitu adanya ketidakadilan (eksploitasi dan aniaya) terhadap kaum fakir miskin dan bukan karena faktor kelebihan semata.

Para modernis melandaskan pandangan mereka dengan merujuk kepada beberapa pandangan Ulama tentang bentuk riba yang dilarang pada masa pra-Islam, di antaranya:

- Pandangan Al-Râzî (w. 1209 M), yaitu ketika menerangkan makna Q.S Âli-'Imrân [3]:130, ia mengatakan "Riba pada masa pra-Islam dapat digambarkan seperti seorang yang memiliki piutang pada orang lain dalam jangka waktu tertentu, apabila, telah jatuh tempo dan orang yang berutang belum mampu melunasinya, si pemberi utang berkata tambahkanlah pada modal dan aku tambah jangka waktunya", maka boleh jadi ia cukupkan 200. Lalu bila sampai tempo yang kedua, ia lakukan lagi hal yang serupa dan demikianlah seterusnya. Maka dia telah mengambil lipat-ganda dari yang seratus tadi (Al-Râzî, 1995:3).

- Ibn Qayyîm al-Jauziyyah (w. 1356 M.), mengatakan bahwa pada masa pra-Islam larangan riba berkaitan dengan aspek moral. Dalam banyak kasus para debitur adalah kalangan miskin yang tidak punya pilihan lain kecuali menangguhkan pembayaran hutangnya, khususnya yang hidup terisolasi di padang pasir. Dan ketika jatuh tempo pembayaran, mereka datang kepadanya dan mengatakan apakah engkau membayar secara kontan atau menambah utangmu (Al-Jauziyyah, 1997:132-136).

- Ibn Taimiyyah (w. 1328 M), berpendapat sebagaimana yang dikutip oleh Kahar Masyhur (1999: 5-6), "Yaitu ketika orang yang berutang mendatangi si pemilik modal saat jatuh tempo pembayaran, lalu pemilik modal mengatakan "apakah kamu mau lunasi atau menambahnya saja" bila yang berutang tidak, atau belum melunasi, maka yang berutang menambahkan pada modal dan si pemilik modal menambah tenggang waktunya. Maka berlipatlah modal tersebut akibat penangguhan pembayaran.

- Al-Tabarî (w. 923 M), Ketika menafsirkan Q.S Âli 'Imrân: (130), ia menjelaskan rangkaian sejarah perilaku orang Arab pra-Islam. 
Yaitu ketika seseorang memberikan hartanya kepada orang lain sebagai hutang, ketika masa pembayarannya tiba, karena si pengutang belum bisa mengembalikan hutangnya dia lalu berkata "beri tangguh aku waktu dan akan kutambah bagimu". Inilah riba berlipat-ganda yang diharamkan Allah. Sebagaimana hadis yang diriwayatkan dari Mujahid, bahwa riba ad'afan muda'âfah merupakan riba jahiliyah. Maka berdasarkan hadis ini ia berpendapat bahwa riba yang diharamkan hanyalah riba yang sama dengan yang dipraktekkan di masa jahiliyah, sedangkan riba jenis lain tidak diharamkan (Al-Tabârî, 1325 H : 59).

- Muhammad 'Abduh (w. 1905 M.), berpandangan, seperti yang dikutip oleh Ridâ (t.th.:332), bahwa: " tidak masuk dalam hukum riba yang diharamkan, jika seseorang memberikan hartanya pada orang lain untuk dikelola lalu menetapkan bagian tertentu baginya dari hasil usahanya kelak Karena muamalah seperti ini menguntungkan kedua belah pihak (pengelola dan pemilik harta).

- Muhammad Rashîd Ridâ (w. 1935 M.), sebagaimana dikutip oleh Bani Syarif Maula (2004:36), mengatakan "Tidak termasuk dalam pengertian riba jika seseorang memberikan kepada orang lain sejumlah harta atau uang untuk diinvestasikan sambil menetapkan kadar tertentu (persentase) baginya dari hasil usaha tersebut, karena transaksi itu menguntungkan bagi pengelola dan pemilik harta. Sedangkan riba yang diharamkan adalah yang merugikan salah seorang tanpa sebab kecuali keterpaksaannya, serta menguntungkan pihak lain tanpa usaha, kecuali melalui penganiayaan dan ketamakan atau berbuat zalim.

Adapun mazhab kedua, yaitu neo-Revivalis yang berarti kebangkitan baru merupakan perpanjangan dan gerakan kebangkitan Islam (Islamic Revivalism) yang muncul pada abad ke-19 dan permulaan abad ke-20 M. Gerakan ini tepatnya tumbuh mulai paruh pertama abad ke $20 \mathrm{M}$. dengan memfokuskan perhatiannya pada berbagai permasalahan penting yang melanda umat Islam khususnya masalah westernisasi, yaitu upaya penyebaran dan penyerapan gaya hidup, kebudayaan atau adat istiadat Barat ke negeri Timur yang dibawa oleh orang Barat atau orang Timur yang pernah menetap di negeri Barat (Al-Barry, t.th.: 784).

Para neo-Revivialis menganggap bunga bank sebagai alat dominasi Barat, dan menuduhnya sebagai penyebab kemerosotan moral, serta munculnya gaya hidup materialistis di kalangan umat Islam, apalagi Barat adalah sumber paham ateis-komunis. Sehingga 
menurut mereka, hal ini harus dibendung agar umat Islam tidak terperdaya dengan lobi dan siasat mereka (Saeed, 1996:12-13).

Kubu ini berusaha membentengi diri dengan menempatkan Islam sebagai way of life (nilai, ideologi, dan sistem hidup) serta menolak menginterpretasikan nass lagi. Prinsip mereka, Alquran dan Sunnah sudah secara kaffah mengatur jalan kehidupan manusia dengan segala kesucian dan kemurmiannya sehingga tidak perlu dicampuri lagi atau dimodifikasi kembali hukum-hukum yang ada di dalamnya dengan memasukkan interpretasi baru yang mempertimbangkan waktu, tempat, kondisi maupun strata sosial. Umat Islam hanya perlu menerimanya sebagai sesuatu yang permanen yang mesti diterapkan dalam realitas kehidupan. Adapun ijtihad hanya dilakukan terhadap permasalahan yang secara eksplisit tidak disebutkan dalam nass (Saeed,1996:13-14).

Dengap logika berpikir demikian, dapat dikatakan bahwa gerakan neo-Revivalis merupakan gerakan yang karakter pemikirannya lebih tekstual sehingga hal tersebut mewarnai cara berpikir mereka dalam menanggapi masalah bunga bank. Para neoRevivalis seperti Abû al-A'lâ al-Maudûdî (w. 1979 M); Hasân alBannâ (w. 1949 M); Sayyid Qutb (w. 1961 M); Mu $\square \mathrm{h} \square$ ammad Qutb (w. 1965 M); dan 'Abd al-Qadîr 'Awdah (w. 1967 M). Mereka cenderung menyamakan bunga bank dengan riba karena dianggap sebagai tambahan yang diperoleh tanpa imbalan, tanpa perlu melihat aspek ketidakadilan dan bentuk riba pada masa pra-Islam sebagai salah satu bahan pertimbangan atas pelarangan tersebut. Menurut mereka larangan riba dalam Alquran harus diambil makna harfiahnya, yaitu hanya uang pokok yang diambil (Muslihun, 2004:120-121). Hal ini sesuai dengan pernyataan dalam Q.S Al-Baqarah [2]: 279:

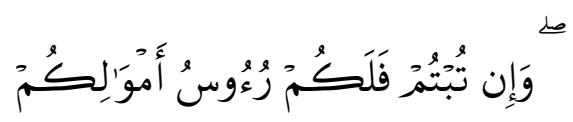

Terjemahnya:

Dan jika kamu bertaubat (dari pengambilan riba), maka bagimu pokok hartamu.

Dengan begitu, tidak ada pilihan kecuali memahami riba sesuai dengan pernyataan nas tersebut. 


\section{PARADIGMA TEKSTUAL}

Yaitu memahami bunga bank dari aspek legal-formal dan secara induktif, berdasarkan pelarangan terhadap larangan riba yang diambil dari teks (nas), dan tidak perlu dikaitkan dengan aspek moral dalam pengharamannya (Mas'adi, 2003: 168). Paradigma ini berpegang pada konsep bahwa setiap utang-piutang yang disyaratkan ada tambahan atau manfaat dari modal adalah riba, walaupun tidak berlipat ganda. Oleh karena itu, betapapun kecilnya, suku bunga bank tetap haram. Karena berdasarkan teori qiyâs, kasus yang akan diqiyas-kan (fara') dan kasus yang di-qiyas-kan (asal) keduanya harus disandarkan pada illat jâlî (illat yang jelas). Dan kedua kasus tersebut (bunga bank dan riba) disatukan oleh illat yang sama, yaitu adanya tambahan atau bunga tanpa disertai imbalan. Dengan demikian, bunga bank sama hukumnya dengan riba.

Adapun di antara tokoh-tokoh fikih Islam kontemporer yang menganut paradigma ini adalah Abû Zahrah, Wahbah Zuhaylî, Yûsûf al-Qardâwî (masing-masing ahli fikih Timur Tengah), Abdul Mannan, Syafi'i Antonio, Adiwarman Azwar Karim (masing-masing ahli hukum Islam dan praktisi perbankan Islam Indonesia).

Yûsûf al-Qardâwî berpendapat bahwa riba yang diharamkan dalam Alquran tidak membutuhkan penjelasan dan pembahasan lebih lanjut, karena tidak mungkin Allah mengharamkan sesuatu kepada manusia yang tidak mereka ketahui bentuknya. Pemahaman riba sesuai yang tertuang dalam Q.S Al-Baqarah [2]:278-279 menunjukkan segala kelebihan dari modal adalah riba, sedikit maupun banyak. Maka setiap tambahan bagi modal yang disyaratkan atau ditentukan terlebih dahulu, karena adanya unsur tenggang waktu semata adalah riba (Al-Qardâwî, 1993:44-45).

Adapun Syafi'i Antonio yang merupakan praktisi dan akdemisi ekonomi Islam di Indonesia, terkait dengan bunga bank, mengatakan bahwa kriteria berlipat-ganda bukanlah syarat terjadinya riba, tapi itu hanya sifat. Artinya, besar atau kecil, bunga bank tetap riba, sebab sifat umum riba adalah berlipat ganda (Antonio, 1999:82).

Hal senada juga diungkapkan oleh Abdul Mannan, yang mengatakan bahwa jika terdapat perbedaan antara riba dalam Alquran dengan bunga dalam masyarakat kapitalis, hal itu hanya merupakan perbedaan tingkat, bukan perbedaan jenis, karena baik riba maupun bunga 
merupakan ekses atas modal yang dipinjam. Walaupun riba dianggap tidak canggih dibandingkan dengan bunga, tetapi menyebut riba dengan nama bunga tidak akan pernah bisa mengubah sifatnya, yaitu adanya tambahan atas modal (Hannan, 1997:120).

Istilah "ekses" dalam kalimat beliau di atas, harus diambil dalam arti yang relatif, karena apa yang mcrupakan ekses layak hari ini, mungkin pada hari esok dianggap suku bunga luar biasa tingginya. Sebagai contoh, dahulu, banyak perkumpulan koperasi Indo-Pakistan yang mengenakan bunga $12-15 \%$ bagi pinjaman (kredit), dan pada waktu itu ekses tersebut dianggap suatu hal yang layak. Sedangkan bila kita bandingkan dengan saat ini, bunga sebesar itu dianggap terlalu tinggi dan mencekik.

Sedangkan Wahbah Zuhaylî dalam (Mas'adi, 2002:166), mengkategorikan bunga bank sebagai riba nasî'ah, karena merupakan kelebihan atau tambahan yang dipungut dengan tidak disertai imbalan, melainkan semata-mata karena penundaan tenggang waktu pembayaran. Demikian pula dengan pemahaman Adiwarman Karim, praktisi perbankan Islam yang sangat concern mengembangkan konsep ekonomi Islam dan perbankan syari'ah, Ia mengatakan, sebagaimana dikutip oleh Muslihun (1994:124) bahwa bunga bank masuk dalam kategori riba nasî'ah. Sebab keberadaan bunga disebabkan adanya perbedaan kualitas, perubahan waktu atau tambahan jumlah antara barang yang diserahkan hari ini dengan barang yang diserahkan kemudian. Jadi, al-ghurm (untung) muncul tanpa adanya al-ghurm (resiko), sementara hasil usaha (al-kharaj) muncul tanpa adanya biaya (daman). Artinya, untung dan hasil usaha muncul hanya karena berjalannya waktu. Padahal dalam bisnis, selalu ada kemungkinan untung dan rugi."

Kelima statemen di atas sesuai dengan apa yang dipertegas oleh Abdullah Saeed (2003:87) yang mengutip pendapat Abû Zahrah dalam bukunya Buhûth fî al-Ribâ: Bahwa apapun keadaannya si pemberi pinjaman tidak punya hak untuk menerima tambahan atas dan melebihi uang pokok ataus modal.

Dengan demikian, para penganut paradigma ini sangat konsisten dengan pesan yang diambil dari ayat terakhir tentang riba yaitu hanya uang pokok yang harus dikembalikan kepada kreditor. Dan oleh karena itu, setiap kelebihan yang ditentukan jumlahnya terlebih 
dahulu, bila melebihi dan di atas uang pokok adalah riba, dan salah satu sifat utama riba adalah berlipat-ganda.

\section{PARADIGMA KONTEKSTUAL}

Yaitu yang memahami bunga bank secara deduktif dan berusaha menilai persangkaan qiyâs bunga bank terhadap keharaman riba dengan mengambil dan menguji konteks masing-masing (Mas'adi, 2002:168).

Dari segi konteks atau illat, pengharaman riba dalam Alquran adalah karena adanya faktor zulm, yaitu memungut tambahan utang dari pihak-pihak yang seharusnya ditolong. Sementara konteks bank adalah niaga (tijârah) untuk mencari keuntungan bersama antara pihak yang punya modal (investor), pihak yang membutuhkan modal (debitur/pengusaha), dan pihak perbankan sebagai mediator dan penyedia jasa. Sehingga sama sekali tidak ada kaitannya dengan tolong menolong antara si kaya dan si miskin, melainkan upaya kerjasama dalam mengembangkan modal dengan menjadikan bank sebagai mediator antara penabung, pengusaha dan bank (Mas'adi, 2002:168). Karena itu, aspek aniaya (ketidakadilan) di sini amat kecil kemungkinan terjadi sebab masing-masing pihak telah saling rela dan mengetahui hak serta kewajibannya masing-masing.

Dengan konsep seperti itu, akhirnya mereka sampai kepada satu kesimpulan bahwa antara riba dengan bunga bank memiliki konteks dan esensi yang berbeda. Riba dianggap kelebihan yang diambil dari pinjaman yang ditujukan untuk keperluan konsumtif, sedangkan bunga bank adalah kelebihan atas pinjaman yang ditujukan dalam rangka, kebutuhan produktif.

Dengan analisis seperti itu, penganut paradigma ini mengharuskan mereka, meninggalkan qiyâs dan lebih memilih mengambil metode istihsân sebagai dasar untuk sampai kepada suatu konklusi hukum yang dianggap lebih tepat untuk dijalankan (Mas'adi, 2002:168). Di antara tokoh dan ahli hukum Islam yang menganut paradigma kontekstual dalam menilai permasalahan bunga bank adalah Munawir Syadzali, Quraish Shihab, Umar Shihab dan M. Dawam Raharjo (masing-masing adalah ulama fikih dan cendekiawan muslim Indonesia). Demikian pula, Fazlur Rahman, Mahmoud Syaltout, dan Mustafa Ahmad al-Zarqa'. 
Menurut Munawir Syadzali dalam (Maula, 2004:38-39), bank adalah suatu lembaga yang terhormat, dan bunga adalah suatu mekanisme bank untuk pengelolaan peredaran uang masyarakat. Anggota masyarakat yang memiliki modal dapat bahkan dihimbau untuk menitipkan uangnya yang tidak digunakan untuk jangka waktu tertentu. Kemudian bank meminjamkannya kepada anggota masyarakat lain yang membutuhkan modal usaha, untuk jangka waktu tertentu pula. Adapun yang meminjam dana tersebut umumnya, untuk keperluan modal usaha, bukan untuk memenuhi kebutuhan konsumtif. Maka berdasarkan prinsip "jangan ada pihak yang dirugikan", tidaklah adil bila, pihak pemilik modal (penabung) yang telah kehilangan hak untuk mempergunakan modalnya dalam jangka waktu tertentu dan juga, pihak bank yang menjadi perantara tidak mendapat imbalan atau kompensasi dari pengorbanan dan jasanya itu. Memang, dapat pula, peminjam dana itu gagal dan merugi dalam usahanya, tetapi pada umumnya masyarakat menerima, dengan baik (rela) dan merasa diuntungkan oleh sistem bunga yang sehat dalam perbankan. Justru dengan penetapan besarnya presentasi bunga yang akan diterima bagi pemilik modal dan besarnya presentasi bunga yang harus dibayarkan oleh peminjam menjadikan keduanya, yakin akar kerjasama tersebut.

Sejalan dengan hal di atas, Umar Shihab menyebutkan bahwa ada empat alasan mengapa bunga bank dihalalkan. Pertama, jumlah bunga yang dipungut dan diberikan pihak bank kepada nasabah jauh lebih kecil dibandingkan dengan riba yang berlaku pada zaman jahiliyah; kedua, pemungutan bunga bank tidak akan membuat bank atau nasabahnya memperoleh keuntungan besar atau sebaliknya tidak akan merasa dirugikan salah satunya dengan pemberian bunga; ketiga, tujuan pengambilan kredit dari debitur pada zaman jahiliyah adalah untuk konsumtif, sedangkan sekarang untuk tujuan produktif; dan. keempat, adanya kerelaan antara kedua pihak yang bertransaksi. Atas dasar itulah, tidak sepantasnya bunga bank diharamkan, sebab meskipun identik dengan riba, tetapi tujuan dan metode pelaksanaannya jauh berbeda dari apa yang dipraktekkan pada masa Jahiliyah yang telah diharamkan dalam Alquran. Oleh karena itu, bunga bank lebih tepat dianalogikan "dengan jual beli yang didasari atas suka sama suka "'an tarâdn" (Muslihun, 1994:126).

Begitu pula, pendapat Raharjo (1996:612-613) bahwa bank sebenarnya adalah modus untuk melaksanakan lembaga bay' (jualbeli), tijârah (niaga) secara suka rela, dan pencegahan sifat riba, yang $a d \square$ 'afan mud $\square \hat{a}^{\prime} a f a h$. Sehingga dalam operasionalnya, minimal 
sebagai perantara, bank membutuhkan komisi, yang pengaturannya ditentukan dan dipantau oleh pemerintah melalui Bank Central. Dengan demikian, bank adalah jalan keluar dari praktek riba karena unsur yang mengharamkan riba, yaitu mengandung paksaan, berlipat ganda dan adanya syarat yang memberatkan, seperti tingkat bunga yang terlampau tinggi, telah hilang dengan adanya peraturan perbankan dan campur tangan pemerintah dalam memantau dan menetapkan aktivitas perbankan.

Meskipun pernyataan di atas tidak secara ekplisit menyebutkan bahwa bunga bank adalah halal, tetapi dengan mengakui eksistensi bank sebagai jalan keluar dari praktek riba, mengindikasikan bahwa sebetulnya ia dapat mentolerir keberadaan bunga bank. Tetapi sungguhpun demikian, ia tetap menghargai bagi mereka yang tetap berkeyakinan bahwa, bunga bank adalah riba, dan pembentukan "bank-bank yang berbasis syari'ah" di Indoneisa sebagai alternatif untuk menghindari riba, serta usaha untuk menjawab tantangan kebutuhan masyarakat akan lembaga perbankan dalam kehidupannya.

Tampaknya, pendirian Raharjo di atas sejalan dengan pandangan Mustafâ Ahmad al-Zarqâ', guru besar hukum Islam dan hukum perdata Universitas Syiria. Selain masih mentolerir eksistensi bunga bank karena darurat, ia juga memberi alternatif dan mendukung keberadaan bank syari'ah. Menurut dia, sistem perbankan yang kita terima sekarang ini merupakan realitas yang tak dapat dihindari. Karena itu umat Islam boleh bermuamalah dengan bank konvensional itu atas pertimbangan dalam keadaan darurat. Akan tetapi umat Islam harus berusaha mencari jalan keluar dengan mendirikan bank tanpa sistem bunga untuk menyelamatkan umat Islam dari cengkraman bank bunga (bank konvensional) (Basyir, 1983:30).

Lain halnya dengan Mahmoud Syaltout dalam Salam (2003:93) yang mengemukakan bahwa kemajuan peradaban manusia telah menimbulkan aktivitas perekonomian baru dan jenis transaksi baru (bank). Selama tidak bertentangan dengan prinsip-prinnsip yang baik menurut tuntutan shara', yaitu tidak ada praktek eksploitasi, maka hal itu dapat dibenarkan.

Dengan pertimbangan seperti itu, di sinilah pentingnya menilai aspek moral sebagai unsur pelarangan riba. Sebab sedih rasanya bila mengabaikan bentuk riba yang bagaimanakah menurut sejarah yang dilarang, mengapa Alquran mencelanya, sebagai perbuatan keji dan kejam, mengapa menganggapnya sebagai tindakan eksploitatif, dan apa sebenarnya fungsi bunga bank pada saat ini (Rahman dalam 
Saeed, 2003:45 dan 75).

Berdasarkan analisis dan pandangan kelompok kontekstual di atas, ada kecenderungan menilai pengertian riba yang diharamkan dari kaca mata konteksnya (kondisi riil), yaitu adanya unsur eksploitasi. Hal ini didasarkan pada beberapa riwayat ahli tafsir klasik dan modern yang mereka pegangi.

Selain itu, pertimbangan kondisi riil bahwa keberadaan bank sekarang ini merupakan kebutuhan atau maslahat al-'ammah wa aldaulah, banyak orang tertolong dan teruntungkan dibanding dengan orang yang teraniaya dengan keberadaannya. Walupun demikian, sebagian mereka tetap mendukung akan keberadaan sistem perbankan alternatif yang menggunakan sistem syari'ah sebagai upaya pengembangan sistem perbankan dan menghargai aspirasi mayoritas kaum muslim.

Dengan demikian, dari dua peta paradigma di kalangan ulama fikih Islam tersebut di atas, titik perbedaan atau mahal al-nizâ ${ }^{\prime}$ (utamanya) terletak pada pemakaian illat riba dalam menilai hukum bunga bank sehingga konklusi yang dihasilkan pun juga berbeda. Namun demikian, pada prinsipnya, semuanya sepakat bahwa riba adalah bentuk muamalah yang tidak dapat ditolerir.

\section{PENUTUP}

Bunga bank dalam kajian hukum (fikih) Islam, merupakan masalah kontemporer yang melahirkan dua paradigma cara berijtihad yang berbeda dalam menentukan status hukumnya, apakah termasuk riba yang diharamkan atau bukan? yaitu paradigma tekstual dan kontekstual.

Perbedaan yang mendasar antara kedua paradigma tersebut adalah cara melihat ilat (sebab adanya hukum) pengharaman riba sebagai hukum asal. Paradigma tekstual memahami illat pengharaman riba terletak pada adanya tambahan, sebagaimana makna yang dikandung oleh kata riba itu sendiri dan berdasarkan konfirmasi nas, bahwa hanya modal pokok yang dapat diambil, sehingga apabila illat itu terdapat di bunga bank, maka bunga bank tersebut adalah riba, dan hukumnya adalah haram.

Kelompok paradigma kontekstual memahami nas dari pengharaman riba secara konteks, yaitu adanya unsur zulm atau eksploitasi yang terjadi pada waktu diharamkannya riba. Sehingga 
kondisi tersebut bila dijumpai pada pemberlakuan bunga bank, barulah bunga bank itu dikategorikan sebagai riba yang status hukumnya jelas, yaitu haram. Kelompok ini melihat bahwa apa yang terjadi di bunga bank tidak ada unsur zulm atau eksploitasi, sehingga mereka menetapkan bahwa bunga bank tidak termasuk riba, dan hukumnya boleh (halal).

\section{DAFTAR PUSTAKA}

al-Ashmâwî, Muhammad Sayyid. 1996. Al-Ribâ wa al-Faîdah fî al-Islâm. Cet. ke-1. Cairo: Maktabat Madbûlî al-Sagîr.

Basyir, Ahmad Azhar. 1983. Hukum Islam tentang Riba, Utang Piutang dan Gadai. Bandung: Al-Ma'arif.

al-Jawziyyah, Ibn Qayyîm. 1997. I'lam al-Muwaqqiîn. Juz ff. Cet. ke-3. Kairo: Dâr al-Hadith.

Kementerian Agama.Wakaf Da'wah, dan Bimibingan Islam. . t.th. AI-Qur' an dan Terjemahnya. Saudi Arabia: t.p.

Harman, M. Abdul. 1997. Teori dan Praktek Ekonomi Islam Yogyakarta: PT. Dana Bhakti Prima Yasa.

Ibn Kathîr. 1994. Tafsîr al-Qur'ân al-Karîm. Juz I. Kairo: Dâr al-Hadîth.

Mas'adi, Ghufton A. 2002. Fiqh Muamalah Kontekstual. Cet. ke-1.. Jakarta: PT. Raja Grafindo Persada.

Masyhur, Kahar. 1999. Beberapa Pendapat Mengenai Riba. Cet. ke-3. Jakarta: Kalam Mulia.

Maula, Bani Syariif. 2004. Perspektif Ekonomi Islam Tentang Bunga Uang; Sebuah Kajian Normatif tentang Hutang-Piutang dalam Perbankan. Himmah. V (13) Mei-Agustus.

Minhajuddin. 1997. Posisi Fiqh Muqaran (Perbandingan) dalam Penyelesaian Masalah Ikhtilafiyah. Ujung Pandang: CV. Berkah Utami.

Muslihun. 2004. Argumen-argumen Baru Pro-Kontra Bunga Bank. Istinbath. I (2). Januari-Juni.

Partanto, Plus A. \& M. Dahlan al-Barry. t.th. Kamus Ilmiah Populer. Surabaya: Penerbit Arkola.

al-Qard $\square$ âwî, Yûsûf. 1993. Fawâ'id al-Bunûk Hiya al-Ribâ al-Harâm; Dirâsat al-Fiqhiyyah fì Dau' al-Qur'ân wa al-Sunnah wa al-Waqi'. Cet. ke-1. Beirut: Mu'assasat al-Risâlah.

al-Râzî, Muh $\square$ ammad Fakhr al-Dîn, 1995. Tafsâr al-Fakhr al-Râzi, jilid V. Juz IX. Cet. ke-2. Beirut: Dâr al-Hadîs.

Raharjo, M. Dawam, 1996. Ensiklopedi Al-Qur'an; Tafsir Sosial Berdasarkan Konsep-konsep Kunci. Cet. ke-1. Jakarta: Paramadina 
Jurnal Hunafa Vol. 5 No. 1, April 2008:45-58

Ridâ, Muhammad Rashîd. t.th. Tafsîr al-Manâr. Juz IX. Cet. ke-2.. Beirut: Dâr al-Fikr.

Saeed, Abdullah, 2003. Bank Islam dan Bunga: Studi Kritis alas Larangan Riba dan Interpretasi Kontemporer. Terjemahan oleh Muhammad Ufuqul Mubin et al. Cet. ke-1. Yogyakarta: Pustaka. Pelajar Offset.

Salam, Arief Abd. 2003. Pembaruan Pemikiran Hukum Islam antara Fakta dan Realita; Kajian Pemikiran Hukum Syaikh Mahmud Syaltut. Cet. ke-1. Yogyakarta: LESPL.

al-Tabarî, Ibn Jarîr. 1325 H. Tafsîr al-Tabârî. Juz IV. Kairo: Maktabat alAmiriyyah. 